\title{
Correlations between Structural and Hardness of Fe-50\% Al Coating Prepared by Mechanical Alloying
}

\author{
Didik Aryanto $^{1,2, *}$, Toto Sudiro ${ }^{1}$, and Agus Sukarto Wismogroho ${ }^{1}$ \\ ${ }^{1}$ Research Center for Physics, Indonesian Institute of Sciences, Serpong 15314, \\ Tangerang Selatan, Banten, Indonesia \\ ${ }^{2}$ Mechanical Engineering, Faculty of Engineering, Universitas Pamulang \\ Jl. Surya Kencana No. 1 Pamulang, Tangerang Selatan, Banten, Indonesia \\ E-mail: *didik_phys@yahoo.co.id
}

Masuk: 3 Agustus 2017 Direvisi : 23 Agustus 2017 Disetujui : 5 September 2017

\begin{abstract}
Fe}-50 \% \mathrm{Al}$ coatings were deposited on the surface of low-carbon steel using mechanical alloying technique at different milling times. The correlation between structure and hardness of coating before and after heat treatment was investigated. At the milling time of less than $180 \mathrm{~min}$, the coating has an elongated lamellar structure. The size of elongated lamellar structure decreased with increasing milling times which led to an increase in the hardness value of coating. After heat treatment, the coating transformed to $\mathrm{FeAl}$ intermetallic phase with a denser structure and uniform in the composition. It affected the hardness of coating. The hardness value of all samples after heat treatment was higher than coating after milling. The hardness of coating was strongly influenced by the morphology and phase of coating.
\end{abstract}

Keywords: Fe-50\%Al, coating, structure, hardness, mechanical alloying

\begin{abstract}
Abstrak: Coating $\mathrm{Fe}-50 \% \mathrm{Al}$ telah dideposisi pada permukaan low-carbon steel menggunakan metode mechanical alloying dengan variasi waktu milling. Hubungan antara struktur dan kekerasan dari coating sebelum dan setelah perlakuan panas telah diteliti. Pada kondisi waktu milling kurang dari 180 menit, coating tersebut memiliki struktur lamellar yang memanjang. Ukuran struktur lamellar yang memanjang tersebut menurun dengan meningkatnya waktu milling, yang mempengaruhi kenaikan tingkat kekerasan dari coating. Setelah proses perlakuan panas, coating tersebut bertransformasi menjadi fasa i FeAl ntermetalic dengan struktur yang lebih padat dan komposisi yang seragam. Hal ini mempengaruhi kekerasan dari coating. Nilai kekerasan dari seluruh sampel setelah perlakuan panas lebih tinggi dibandingkan coating setelah milling. Kekerasan dari coating sangat dipengaruhi oleh morfologi dan fasa coating tersebut.
\end{abstract}

Kata kunci: Fe-50\%Al, coating, struktur, kekerasan, mechanical alloying

\section{INTRODUCTION}

Low carbon steel is extensively utilized in the construction sectors and various applications, due to their low cost than high-alloy steels and good mechanical properties as well [1,2]. However, low carbon steel has poor oxidation and corrosion resistance especially at high temperature, which restricts to their applications. Investigation on the fabrication of high resistant coating against oxidation and corrosion on low carbon steel is considered as an essential and promising task for solving the problem. Metals which can form continuous and stable oxides are widely believed to be suitable for fabricating anti-oxidation and corrosion coatings [3]. Aluminium (Al)-based can be apply as coating to isolate and act as a shield against the aggressive corrosive elements. This is due to their ability to form highly densified protective $\alpha-\mathrm{Al}_{2} \mathrm{O}_{3}$ layers. Al-coatings offer a combination of attractive properties such as low density, ease of fabrication and resistance to oxidation at high temperature [4], but their have poor mechanical and physical properties. One way to improve the mechanical and physical properties of $\mathrm{Al}$ coating at high temperatures is carried out by adding Fe element. The presence of $\mathrm{Fe}$ in $\mathrm{Al}$ matrix results in the formation of secondary phases, which causes the microstructural stability of Al-Fe [5]. In addition, the previous study reported that the grain refinement to the sub-micrometer or even to the 
nanocrystalline size can improve the mechanical and physical properties of Al-alloys [6]. Mechanical alloying is one of the top-down techniques used for reducing the grain size of the materials. This method can be used to produce ultra fine and uniform powders, which is now widely applied for preparation of intermetallics, extended solid solutions and amorphous phases of powders [3,7].

Recently, mechanical alloying method has been used to deposit thick multi-component structures with high bond ability on different substrates, such as TiAl on Ti substrate [8], $\mathrm{TiCr}$ and $\mathrm{TiCu}$ on Ti-6Al-4V substrate [9], $\mathrm{NiAl}$ on carbon steel [10,11], $\mathrm{Al}$ on low carbon steel [1], $\mathrm{Cr}$ on $\mathrm{Cu}$ substrate [12], hydroxyapatite on Ti substrate [13], $\mathrm{CrAl}$ on low carbon steel [2], CrAl on $\mathrm{Cu}$ substrate [3], and TiC on AISI D2 steel substrate [14]. The present work focuses to discuss the correlation between structural of $\mathrm{Fe}-50 \% \mathrm{Al}$ coatings before and after annealing at $600^{\circ} \mathrm{C}$ and their hardness.

\section{EXPERIMENT}

A detail of experimental procedure for the sample preparation has been described elsewhere [15]. Here, we briefly repeated the experimental. For the experiment, low-carbon steel plates were used as substrate with a dimension of $10 \times 8 \times 3 \mathrm{~mm}^{3}$. Before coating process, the surface of the steel plates was polished using SiC papers for up to No. 1200 and cleaned with standard cleaning method to remove contaminants from the surface. The commercial $\mathrm{Fe}(99,5 \%$ purity) and $\mathrm{Al}(99,5 \%$ purity) powders were used as raw material. In order to deposit $\mathrm{Fe}-$ Al coating on the surface of low carbon steel, the two steps of milling were carried out using high speed shaker mill.

The phase structure of $\mathrm{Fe}-50 \% \mathrm{Al}$ coating before and after heat treatment was identified by X-ray diffraction (XRD) (SmartLab-Rigaku Co. Ltd., Japan), using a continuous scan mode. The morphology of the Fe-50\% $\mathrm{Al}$ coatings was characterized from cross-sectional sample using scanning electron microscope (SEM-Hithaci High-Tech Co. Ltd, Japan) with back-scattered electron (BSE) mode. The hardness of Fe-50\%Al coating was measured from the cross-sectional sample using a Vickers Microhardness tester (LM-100AT) at a load of $500 \mathrm{kgf}$ and a dwell time of $15 \mathrm{~s}$.

\section{RESULT AND DISCUSSION}

Figure 1 shows the XRD pattern of low carbon steel plate. The $2 \theta$ values were compared to the standard ICDD data card (04-014-0360). The XRD pattern of low carbon steel plate exhibits sharp and narrow peaks. They have a strong preferred orientation along the (110) plane at $2 \theta=44.67^{\circ}$. Other diffraction peaks, (200) and (211), with less intensity were also found. The results indicate that the low carbon steel exhibits a polycrystalline with a body-centered-cubic (bcc) structure.

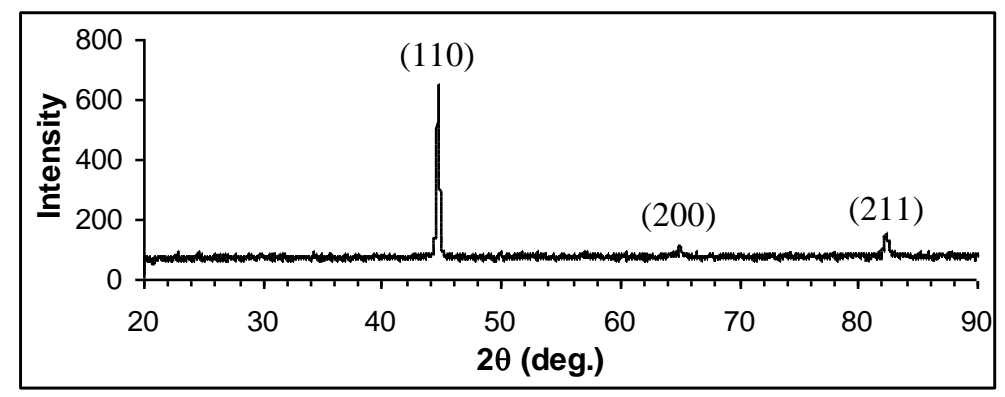

Figure 1. XRD pattern of low carbon steel plate.

Figure 2 shows the morphology from cross-section of $\mathrm{Fe}-50 \% \mathrm{Al}$ coating prepared at different milling times. The coating thickness and formed phase on Fe-50\% Al coating after mechanical alloying were discussed elsewhere [15]. The summarizing results are given in Table 1. The XRD analysis (in the Table 1) shows the diffraction peak of $\mathrm{Al}$ dan Fe. This provides an evidence of the deposition of Fe-Al coating on the low carbon steel surface. The presence of $\mathrm{Al}$ phase implied that no intermetallic phase formed during mechanical alloying process [3]. The Fe and $\mathrm{Al}$ element in the $\mathrm{Fe}-50 \% \mathrm{Al}$ coating is separated when the milling time is less than 180 min. Liu et al. show that an elongated lamellar of the $\mathrm{Fe}-40 \mathrm{Al}-5 \mathrm{Cr}$ powder revealed that the element is not reacted and difference in the composition [16]. The cross-section Fe-50\% Al coating in this research supports that the $\mathrm{Fe}-\mathrm{Al}$ element is not reacted and difference in the composition. After milling for $180 \mathrm{~min}, \mathrm{the} \mathrm{Fe}(\mathrm{Al})$ 
solid solution is formed. This could be related to the dissolution of $\mathrm{Al}$ into Fe. The result also shows that the elongated lamellar structure becomes finer, resulting uniform microstructure (Figure 2d). The Fe-50\% Al powder particles trapped between the ball and substrate prior to adhere on the substrate surface [1]. Increasing the duration of mechanical milling, the collision between ball and substrate leads to increase in the plastic deformation. It causes that the particle had a tendency to consolidate into bulk material and the coating layer was denser (Figure 2d) [10].
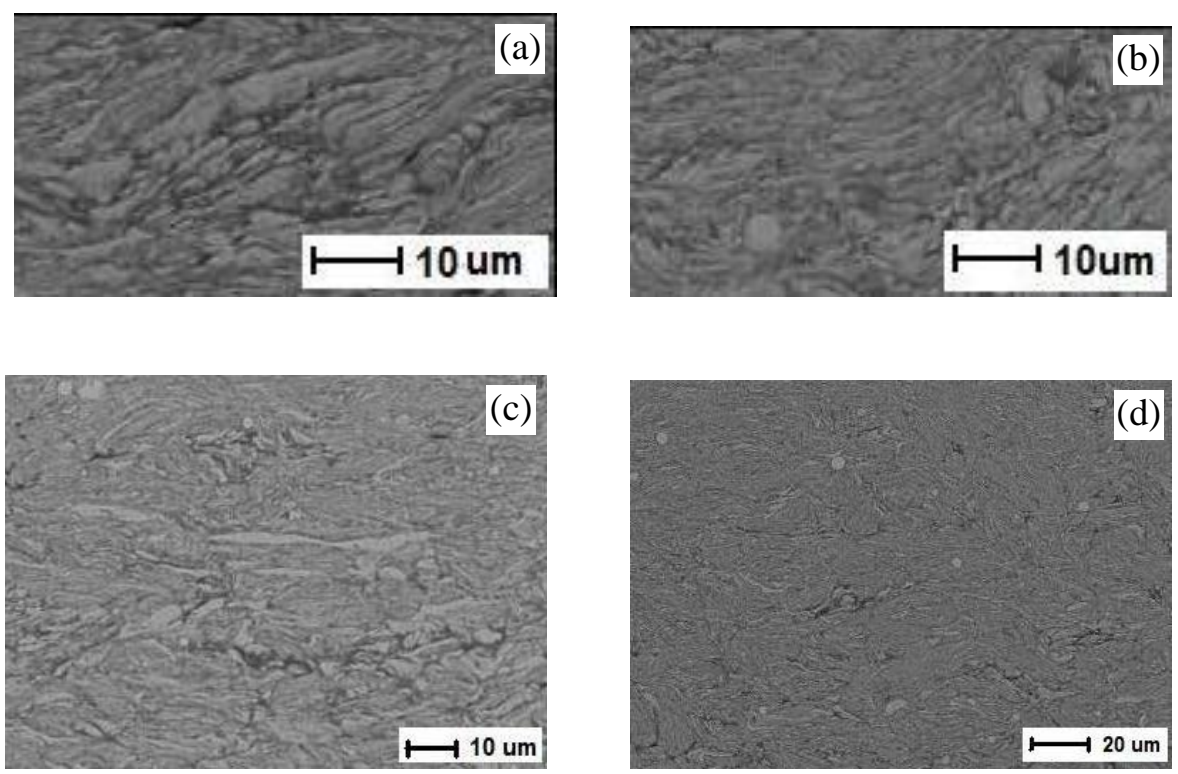

Figure 2. Microstructure features from cross-section of Fe-50\% $\mathrm{Al}$ coating on low carbon steel prepared at different milling time for (a) $30 \mathrm{~min}$, (b) $60 \mathrm{~min}$, (c) $120 \mathrm{~min}$, and (d) $180 \mathrm{~min}$.

Table 1. Phase structure of Fe-50\%Al coating prepared by MA at different milling times.

\begin{tabular}{lclc}
\hline Process type & Thickness $(\mu \mathrm{m})$ & Phases & Structure \\
\hline MA for 30 min. & 38.71 & $\mathrm{Fe}, \mathrm{Al}$ & $\mathrm{bcc} / \mathrm{bcc}$ \\
MA for $60 \mathrm{~min}$. & 92.90 & $\mathrm{Fe}, \mathrm{Al}$ & $\mathrm{bcc} / \mathrm{bcc}$ \\
MA for $120 \mathrm{~min}$. & 103.87 & $\mathrm{Fe}, \mathrm{Al}$ & $\mathrm{bcc} / \mathrm{bcc}$ \\
MA for $180 \mathrm{~min}$. & 141.94 & $\mathrm{Fe}(\mathrm{Al})$ & $\mathrm{Bcc}$ \\
\hline
\end{tabular}

The structure evolution of $\mathrm{Fe}-50 \% \mathrm{Al}$ coating after heat treatment at $600^{\circ} \mathrm{C}$ for $2 \mathrm{~h}$ was investigated [15] and the summarizing results are given in Table 2. From XRD analysis, the Fe and Al element transform into FeAl intermetallic phase after heat treatment. No phase related to $\mathrm{Al}, \mathrm{Fe}$, or oxidation product of $\mathrm{Fe}$ and $\mathrm{Al}$ were found in the XRD analysis of all samples. Similar result is shown by Haghighi et al., the formation of FeAl intermetallic was occured at the $\mathrm{Fe}-50$ at.\% Al powder after annealing process [17]. During heat treatment, a solubility of $\mathrm{Al}$ in $\mathrm{Fe}$ matrix affects the formation of secondary phase between $\mathrm{Fe}$ and $\mathrm{Al}$ [5]. Similar result was shown in the NiAl coating on Ti substrate by Mohammadnezhad et al. [10]. The dissolution of $\mathrm{Al}$ into Ni caused the formation of $\mathrm{NiAl}$ intermetallic. SEM image from cross-section of the $\mathrm{Fe}-50 \% \mathrm{Al}$ coating at varying milling times after heat treatment at $600^{\circ} \mathrm{C}$ for $2 \mathrm{~h}$ are shown in Figure 3. The elongated laminar structure is not observed in the microstructure of $\mathrm{Fe}-50 \% \mathrm{Al}$ coating after heat treatment. However, some larger size granular and porosity were observed in the microstructure of all samples. The diffusion of $\mathrm{Al}$ in the $\mathrm{Fe}$ matrix is believed affect the formation of porosity. The larger granular may come from the original structure of $\mathrm{Fe}-50 \% \mathrm{Al}$ coating before heat treatment. Compared with $\mathrm{Fe}-50 \% \mathrm{Al}$ coating after milling, coating after heat treatment has uniform structure. It is shown by the uniform colour in the BSE SEM images. The results of SEM characterization confirm the results of XRD analysis, which shows that the Fe and Al element completely reacted to form FeAl intermetallic. 
4 | Didik Aryanto, dkk., Correlations between Structural and Hardness....,

Table 2. Evolution of structure of Fe-50\% Al coating prepared at different milling times after heat treatment at $600^{\circ} \mathrm{C}$ for $2 \mathrm{~h}$.

\begin{tabular}{lcccc}
\hline Process type & Phase & Structure & Crystalline size $(\AA)$ & Lattice strain $(\%)$ \\
\hline MA for 30 min. & FeAl & Bcc & 5.16373 & 0.1787 \\
MA for 60 min. & FeAl & Bcc & 4.89214 & 0.1890 \\
MA for 120 min. & FeAl & Bcc & 3.44234 & 0.2682 \\
MA for 180 min. & FeAl & Bcc & 4.92384 & 0.1879 \\
\hline
\end{tabular}
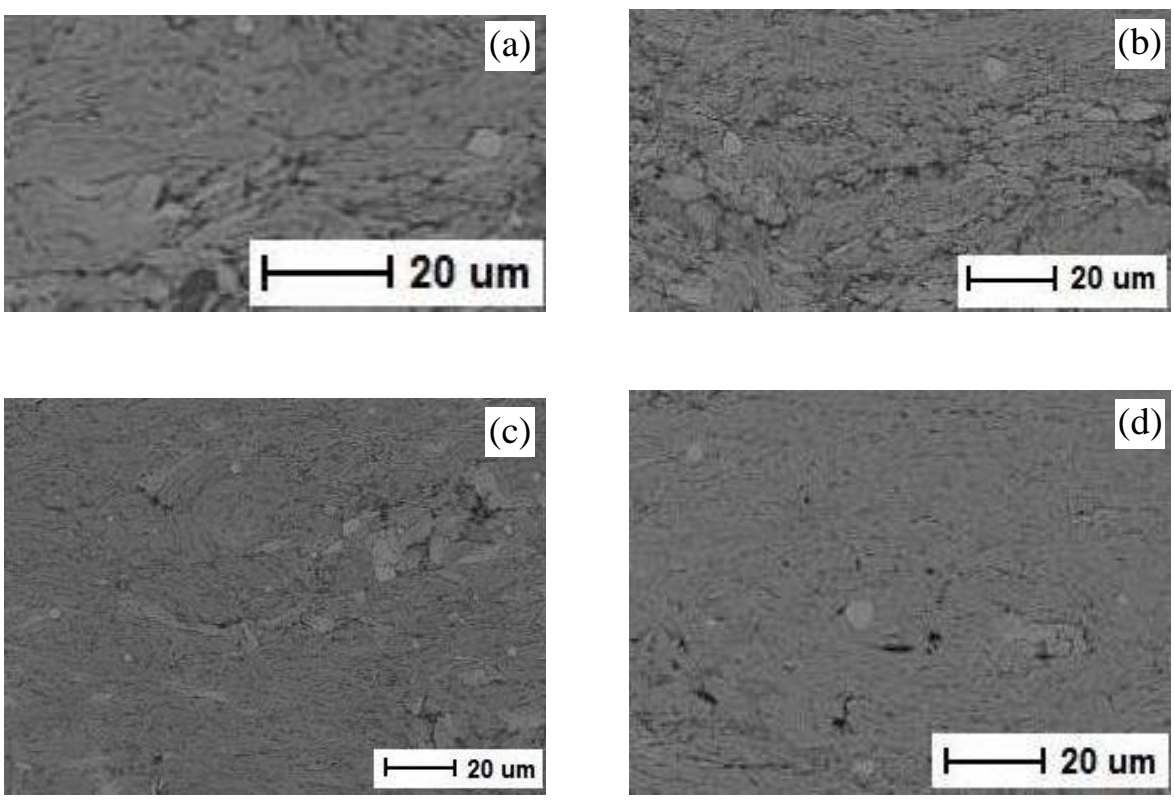

Figure 3. Microstructure features from cross-section of $\mathrm{Fe}-50 \% \mathrm{Al}$ coating on low carbon steel prepared at different milling time for (a) $30 \mathrm{~min}$, (b) $60 \mathrm{~min}$, (c) $120 \mathrm{~min}$, and (d) $180 \mathrm{~min}$ after heat treatment.

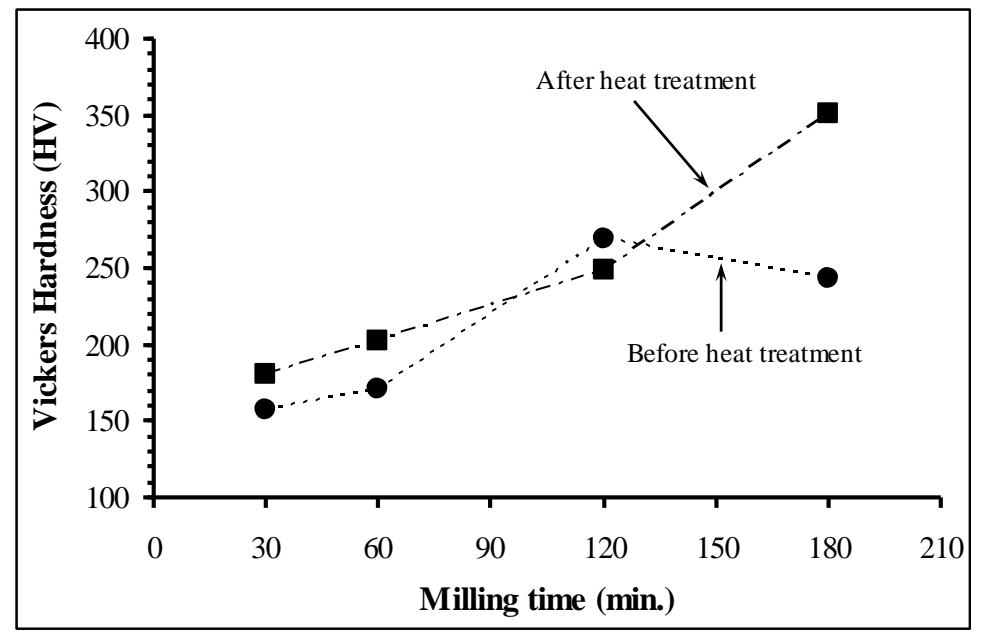

Figure 4. Vickers Hardness of Fe-50\%Al coating on low carbon steel prepared at various milling time before and after heat treatment at $600^{\circ} \mathrm{C}$.

Vickers hardness testing was carried out to evaluate the hardness of the Fe-50\% Al coating. Figure 4 shows the result of cross-section microhardness of $\mathrm{Fe}-50 \% \mathrm{Al}$ coating at different milling times as milled and after annealing. The hardness of Fe-50\% Al coating after milling increases with increasing milling time. It may be attributed to the reduction in the grain size of coating (as show in the Figure 2a-d) [18]. After milling time for $180 \mathrm{~min}$, however, the hardness of $\mathrm{Fe}-50 \% \mathrm{Al}$ is decreased. Similar result was shown in the NiAl coating prepared using a mechanical alloying technique [10]. The optimum coating hardness is obtained at specific milling time, after that the coating hardness decreases. The different between the compressive residual stresses in the coating prepared at different milling time is believed to affect the hardness of the coating [10,12]. Other 
studies show that the smallest grain size leads to some softening for finest nanocrystallites which causes the hardness falls [7]. The small grain size becomes impossible to accommodate the several dislocations which are required to form pile-up at the grain boundary [19]. The hardness of $\mathrm{Fe}-50 \% \mathrm{Al}$ coating after heat treatment is higher than before heat treatment. It linearly increases with increasing milling time. This can be attributed to the existence of $\mathrm{FeAl}$ intermetallic compound. The increase in the hardness of coated layer after heat treatment is also due to a denser structure. As shown in SEM images (Figure 3a-d), the microstructure of coating exhibits finer grain and low porosity. It may cause by the $\mathrm{Al}$ diffusion in the Fe matrix during heat treatment.

Figures 5 and 6 show the Vickers indented morphologies of $\mathrm{Fe}-50 \% \mathrm{Al}$ coating before and after heat treatment, respectively. The result shows that the $\mathrm{Fe}-50 \% \mathrm{Al}$ coating before heat treatment is ductile. It is indicated by the absence of crack in the corner of indented samples after Vickers indentation by using a load of $500 \mathrm{kgf}$ for 15 second. It could be related to that the elements of $\mathrm{Fe}$ and $\mathrm{Al}$ are not reacted after the coating process using MA (as shown on XRD analysis in Table 1). The hardness of Fe-50\% $\mathrm{Al}$ coating after milling higher than the hardness of $\mathrm{Fe}(90 \mathrm{Hv})$ [2] and pure $\mathrm{Al}(17.03 \mathrm{Hv})$ [20]. In this case, the difference in the hardness may be attributed to the grain size [18] of coating. The optical microscope images of $\mathrm{Fe}-50 \% \mathrm{Al}$ coating after heat treatment indicate the existence of irregular cracks on the indented section (Figure 6). This is due to the formation of FeAl intermetallic phase after heat treatment (as shown on XRD analysis in Table 2). Risanti et al. show that intermetallic phase is brittle at the room temperature [21]. Study on WC-FeAl composite by Furushima et al. revealed that the Vickers hardness is influenced by the generation of the h-phase [22]. The hardness value of $\mathrm{Fe}-50 \% \mathrm{Al}$ coating in this study is smaller than the $\mathrm{FeAl}$ intermetallic $(470 \mathrm{Hv})$ as presented by Ozaki and Kutsuna [23]. It may be influenced by the non uniform particle size distribution and the presence of pores in the coating (as shown on the SEM image in the Figure 3). The result strongly suggests that the hardness value is affected by the phase, grain size, and porosity of coating layer.

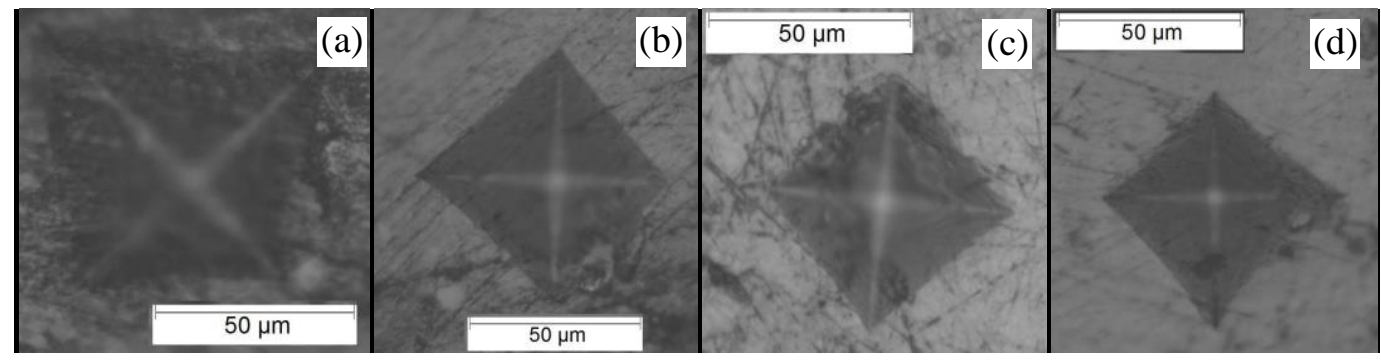

Figure 5. Optical microscopy images showing the indentation impressions produced with a load of $500 \mathrm{kgf}$ for 15 second in the Fe-50\%Al coating after milling time for (a) $30 \mathrm{~min}$, (b) $60 \mathrm{~min}$, (c) $120 \mathrm{~min}$, and (d) $180 \mathrm{~min}$.
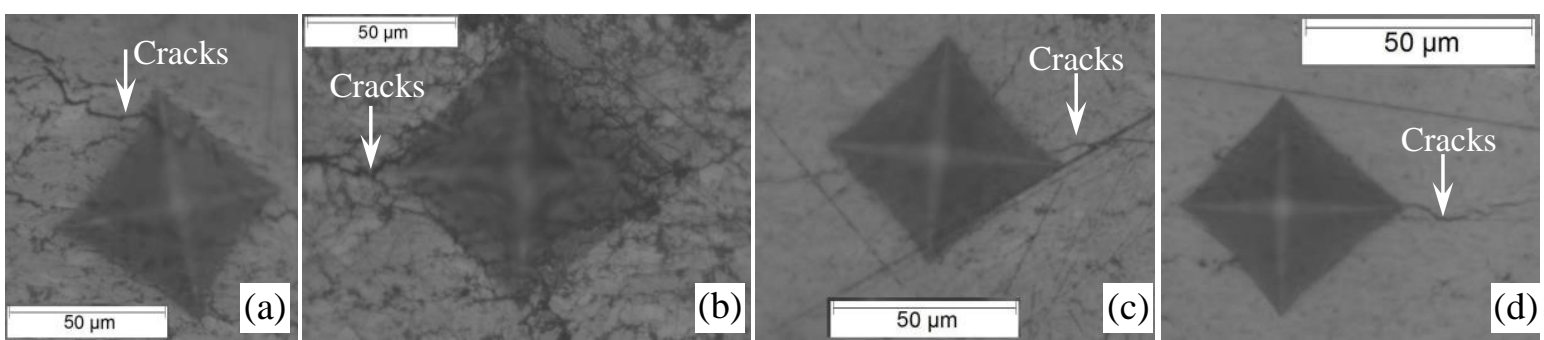

Figure 6. Optical Microscopy images showing the indentation impressions produced with a load of $500 \mathrm{kgf}$ for 15 second in the $\mathrm{Fe}-50 \% \mathrm{Al}$ coating after heat treatment at $600^{\circ} \mathrm{C}$ with milling time for (a) $30 \mathrm{~min}$, (b) $60 \mathrm{~min}$, (c) $120 \mathrm{~min}$, and (d) $180 \mathrm{~min}$.

\section{CONCLUSIONS}

Mechanical alloying technique was used to deposit Fe-50\%Al coating on the surface of low carbon with various milling times. The structure of coating layer was strongly influenced by the milling time during mechanical alloying process. It also affected the coating hardness. Increasing milling time caused the reducing size of elongated lamellar structure in the coating and the increasing thickness and hardness values of coating. After heat treatment, the hardness value of all samples was increased and higher than that of after milling. It was caused by the formation of FeAl intermetallic and a denser coating structure. In this study, the morphology and phase of coating were strongly correlated to the hardness values. 
6 | Didik Aryanto, dkk., Correlations between Structural and Hardness....,

\section{ACKNOWLEDGEMENT}

The authors gratefully acknowledge the financial support from Indonesian Institute of Sciences. We would like to thank Prof. Perdamean Sebayang for the fruitful discussion.

\section{REFERENCE}

[1] Canakci A, Erdemir F, Varol T and Ozkaya S 2013 Powder Technology 24724

[2] Sudiro T, Sebayang P, Aryanto D, Hia A I J and Sebayang K 2015 Teknologi Indonesia 38156

[3] Chen C, Zhang J, Duan C, Feng X and Y Shen 2016 J. Alloys and Compounds 660208

[4] Chaliampalias D, Vourlias G, Pavlidou E, Stergioudis G, Skolianos S and Chrissafis K 2008 Applied Surface Science 2553104

[5] Baig M, Ammar H R and A H Seikh 2016 Materials Science \& Engineering A 655132

[6] Průša F, Vojtěch D, Bláhová M, Michalcová A, Kubatík T F and J Č́ížek 2015 Materials and Design 7565

[7] Mhadhbi M, Khitouni M, Escoda L, Sũnol J J and Dammak M 2011 J Alloys and Compounds 5093293

[8] Romankov S, Sha W, Kaloshkin S D and Kaevitser K 2006 Surface and Coatings Technology 2013235

[9] Li B, Ding R, Shen Y, Hu Y and Guo Y 2012 Materials and Design 3525

[10] Mohammadnezhad M, Shamanian M and Enayati M H 2012 Applied Surface Science 263730

[11] Mohammadnezhad M, Shamanian M, Enayati M H and Salehi M 2013 Surface and Coatings Technology 21764

[12] Li Y, Chen C, Deng R, Feng X and Shen Y 2014 Powder Technology 268165

[13] Zadorozhnyy V Y, Kaevitser E V, Kopylov A N, Borisova Y V, Sudarchikov V V, Khasenova R S, Gorshenkov M V, Zadorozhnyy M Y and Kaloshkin S D 2015 Surface \& Coatings Technology 281157

[14] Saba F, Kabiri E, Khaki J V and Sabzevar M H 2016 Powder Technology 28876

[15] Aryanto D, Wismogroho A S and Sudiro T 2016 Jurnal of Physics: Conference Series 739 012132(1-5)

[16] Liu H, Tang W, Wang Y, Liu C, Xu G and Zheng Z 2010 J. Alloys and Compounds 506963

[17] Haghighi S E, Janghorban K and Izadi S 2010 J. Alloys and Compounds 495260

[18] Gu J, Gu S, Xue L, Wu S and Yan Y 2012 Materials Science \& Engineering A 558684

[19] Conrad H and Narayan J 2000 Scr. Mater. 421025

[20] Samsonov G V 1968 Handbook of the physicochemical properties of the element (New York: IFI/Plenum)

[21] Risanti D, Deges J, Falat L, Kobayashi S, Konrad J, Palm M, Pöter B, Schneider A, Stallybrass C and Stein F 2005 Intermetallics 131337

[22] Furushima R, Katou K, Shimojima K, Hosokawa H, Mikami M dan Matsumoto A 2015 Intermetallics 66120

[23] Ozaki H and Kutsuna M 2012 Dissimilar Metal Joining of Zinc Coated Steel and Aluminum Alloy by Laser Roll Welding Welding Processes ed R Kovacevic (USA: InTech) Chapters 2 pp 33-54 